\section{Grundig om validitet}

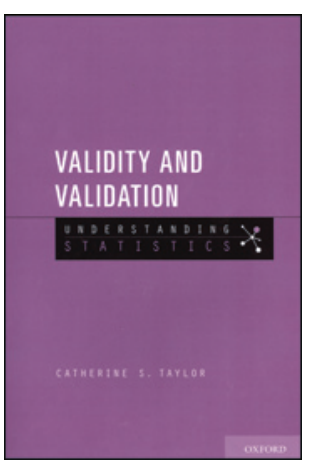

Catherine S. Taylor

Validity and validation

Understanding Statistics. 224 s, tab, ill.

Oxford: Oxford University Press, 2013.

Pris GBP 21

ISBN 978-0-19-979104-0

\section{Lærebok med kjedelig layout}

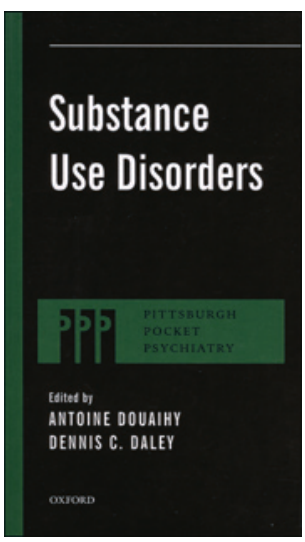

Antoine Douaihy, Dennis C. Daley, red.

Substance use disorders

397 s, tab, ill. Oxford: Oxford University Press, 2013. Pris GBP 40

ISBN 978-0-19-989816-9
Dette er en liten «lefse» av en bok med en litt kjedelig, men presis tittel, utgitt i serien Understanding Statistics. Det siste virker jo lovende. Spørsmålet er om temaet behandles på en tilstrekkelig interessevekkende måte. Målet er å definere validitet og å beskrive hvilke faktorer som er viktige når man vurderer forskningsresultater. Det er opplagt et viktig tema. Det publiseres mange artikler der det er grunn til å tvile på om konklusjonen holder. Alle som vurderer forskningsarbeider og manuskripter, gjenkjenner problemer knyttet til mangel på intern og/eller ekstern validitet som klassiske gjengangere.

Det innledende kapitlet om validitet og validering er nyttig. Det gir grunnleggende informasjon om validitetsteori og oppsummerer spesifikke utfordringer i forskning. På mange måter fungerer det som en kort oppsummering av resten av boken, og det er lesbart som minimumskunnskap for alle. Resten er delt inn i kapitler som går mer grundig inn på temaer som intern validitet, eksterne trusler mot validitet, validitet av statistiske konklusjoner og validering av spørreskjemaer, samt en avslutning med en liten dose vitenskapsfilosofi og oppsummering av kapitlene.

Denne publikasjonen er best der den gir konkrete råd og for eksempel sammenlikner styrker og svakheter direkte knyttet til forskjellige eksempler på forsøksplaner, for eksempel i kapitlet om intern validitet. Den omtaler også validitet av statistiske konklusjoner helt greit - i alle fall hvis man allerede er godt kjent med begreper som styrke, signifikanstester, type I- og II-feil, effektstørrelse og liknende, men 15 små sider med konsentrert informasjon om statistikk gir noen pedagogiske begrensninger.

Hva kan så denne boken lære oss? Og hvem er den primært skrevet for? Den er tydelig basert i den psykometriske tradisjonen snarere enn den medisinske, og jeg gjetter at et flertall av forskere innen anvendt medisin vil oppleve den som i overkant teoretiserende. Det betyr ikke at det ikke finnes mye bra - det er bare litt tungt å finne frem til gullkornene. Det er mye tekst og lite luft, relativt få figurer og tabeller, og det er dessverre ikke gjort bruk av tekstbokser for å fremheve hovedbudskap. Har man ikke allerede oppdaget og forstått at validitet er grunnleggende i all forskning, tror jeg dessverre ikke dette er lesning som vil lede til aha-opplevelser og bedre kvalitet på medisinske forskningsprosjekter.
Dette er en lærebok for leger i spesialisering i psykiatri eller rusmiddelmedisin. Ambisjonen er å formidle oppdatert bredde- og dybdekunnskap om biologiske, psykologiske og sosiale aspekter ved rusmiddellidelser. Boken er i lommeformat og er skrevet i kun 8 pkt skrift. Tabeller og kasuistikker har grå bakgrunn. De få illustrasjonene er i nyanser av grått, og flere har mangelfull forklarende tekst. Noen avsnitt inneholder en del trykkfeil. Slikt skjemmer helhetsinntrykket.

De 13 kapitlene beskriver blant annet ulike rusmidlers egenskaper, nevrobiologi, epidemiologi, sosiale og samfunnsmessige aspekter, familieperspektiv, kartlegging og diagnostikk, farmakoterapi, psykososial behandling, komorbiditet, forebygging og skadereduksjon. Hepatitt C- og hivinfeksjoner har fătt et eget kapittel, det samme har rusmiddellidelser blant ungdom. Hvert kapittel innledes med en oversikt over kapitlets hovedpunkter og avsluttes med en fyldig litteraturliste. Hvert underkapittel starter på ny side, noe som bidrar til god plass for egne notater. Bakerst finnes tabeller over selvhjelpstilbud og profesjonelle organisasjoner.

Selv om ambisjonen er en helhetlig fremstilling av fagområdet, savnes omtale av en del vanlige rusmidler, som inhalanter, GHB, khat og syntetiske rusmidler. Nikotin er i noen kapitler tatt med, andre ganger utelatt. En del informasjon gjentas i ulike kapitler. Dette kan skyldes at 16 ulike forfattere har bidratt. Noen av forfatterne refererer til forrige versjon av det amerikanske diagnosesystemet, DSM-IV-TR, som var gjeldende da manuset ble skrevet, mens andre redegjør for sannsynlige endringer i DSM-5, som ble innført mens boken var til trykking. Utgivelsen kunne med fordel ha vært utsatt noen måneder, slik at den konsekvent kunne ha referert til den endelige utgaven av DSM-5. Ventetiden kunne redaksjonen ha benyttet til bedre redigering og korrekturlesing.

Ambisjonen om å tilføre dybdekunnskap er uoppnåelig med det begrensede formatet. Utgivelsen gir imidlertid en innføring i et bredt fagfelt, og for norske fagpersoner kan det være interessant å få et innblikk i de amerikanske program- og manualbaserte behandlingstilbudene. Andre bøker vil nok være mer relevante som kjernelitteratur for fremtidige norske spesialister.

\section{Anne-Marit Langås}

Psykiater, Kongsberg 